\title{
Anti-hiperglycemic effect of Quassia amara (Simaroubaceae) in normal and diabetic rats
}

FERREIRA S.F.; AZEVEDO S.C.S.F.; VARDANEGA-PEICHER M.; PAGADIGORRIA C.L.S.; GARCIA R.F. * Department of Physiological Sciences, State University of Maringá, CEP 87020-900, Maringá-Pr, Brazil, phone/ fax: (44) 3011-4702, *rfgarcia@uem.br

\begin{abstract}
The anti-hyperglycemic effect of wood powder of Quassia amara (QA) was evaluated in normal and in alloxan diabetes-induced rats. After a $12 \mathrm{~h}$ fast and glycemic check, the animals were orally given $0.9 \%$ of saline (control group), metformin $(500 \mathrm{mg} / \mathrm{kg}$ ) or QA (200 mg/kg) and, 30 minutes later, they received an oral glucose dose $(1 \mathrm{~g} / \mathrm{kg})$. The blood glucose level was measured after 30, 60, 90 and 120 minutes. From the oral glucose dose, QA showed anti-hyperglycemic effects, similar to metformin, only in the diabetic animals $(p<0.01)$ when compared to the control group. Although the anti-hyperglycemic mechanism of action of QA was not investigated, a mechanism similar to metformin can be suggested, since both presented similar results for the conditions tested, that is, normal and diabetic rats. It is believed that the use of QA in diabetics could help to control the blood glucose levels and be useful as an alternative therapy.
\end{abstract}

Keywords: alloxan, anti-hyperglicemic effect, diabetes, Quassia amara

\begin{abstract}
RESUMO: Efeito anti-hiperglicêmico de Quassia amara (Simaroubaceae) em ratos normais e diabéticos. O efeito anti-hiperglicemiante do pó do lenho de Quassia amara (QA) foi avaliado em ratos normais e diabéticos aloxana induzidos. Após jejum de 12 horas e verificação da glicemia, os animais receberam administração oral de salina $0.9 \%$ (grupo controle), metformina ( $500 \mathrm{mg} / \mathrm{kg}$ ) ou QA (200 mg/kg) e 30 minutos depois carga oral de glicose $(1 \mathrm{~g} / \mathrm{kg})$. A glicemia foi medida nos próximos 30, 60, 90 e 120 minutos. A partir da carga oral de glicose, a QA mostrou efeito anti-hiperglicemiante, similar a metformina, somente nos animais diabéticos $(p<0.01)$ quando comparados ao grupo controle. Embora o mecanismo de ação anti-hiperglicemiante da QA não tenha sido investigado, podemos sugerir um mecanismo semelhante à metformina, visto que ambos apresentaram resultados similares nas duas condições testadas, ou seja, animais normais e diabéticos. Acredita-se que o uso de QA, em diabéticos, possa auxiliar no controle da glicemia e servir como terapia alternativa.
\end{abstract}

Palavras-chave: aloxana, efeito anti-hiperglicemiante, diabetes, Quassia amara

\section{INTRODUCTION}

Chronic diseases are the major causes of death in developed countries and large Brazilian cities. Among them is Diabetes Mellitus (DM), a complex and debilitating disease characterized by extensive biochemical changes due to the absolute or relative lack of insulin or the inefficacy of its peripheral actions. The major symptoms of diabetes are polyuria, polidipsia and polyphagia, and its diagnosis is made by the detection of hyperglycemia and glycosuria (Silva-Costa et al., 2008). Most of the consequences of diabetes result from micro and macrovascular complications; the most common comorbidities linked to DM are renal failure, amputation of lower limbs, blindness, and cardiovascular disease, including coronary artery diseases and encephalic vascular accidents (Toscano, 2004). Conventionally, the insulin-dependent DM is treated with exogenous insulin (Felig et al., 1995), and the non-insulin-dependent DM with synthetic oral hypoglycemic agents such as sulphonylureas and biguanides (Rosac, 2002). However, most of the times the therapeutic administration of insulin is made difficult by the huge variation from patient to patient in their response to insulin therapy and for its dose and frequency (Sebbag et al., 1994), and synthetic oral drugs can cause adverse health effects (Raheja, 1977).

Although the literature does not describe the use of Quassia amara (QA) in the treatment of $D M$, the reports of the ingestion of this plant as an alternative treatment or in association with

Recebido para publicação em 02/05/2011

Aceito para publicação em 23/11/2012

Rev. Bras. PI. Med., Campinas, v.15, n.3, p.368-372, 2013. 
conventional agents by individuals having type II $\mathrm{DM}$ is quite common.

There are many studies on the anti-diabetic active principles and/or results of pharmacological tests demonstrating the experimental and/or clinical anti-diabetic effectiveness of medicinal plants (Groover et al., 2002; Li et al., 2004). Several Brazilian plants are used as hypoglycemic agents (Provasi et al., 2005; Borges et al., 2008; Ferreira et al., 2008; Medeiros et al., 2009), some of them with scientific proof of their effects. For some phytotherapeutic agents, though, the hypoglycemic effect is the result of liver toxicity (Negri, 2005).

Many phytotherapeutic agents with hypoglycemic action mimic one or more of the actions of insulin at the receptor or downstream. Other actions include: stimulate insulin release; increase the sensitivity of the insulin receptors; increase glucose use by the tissues; correct the protein and lipid metabolic disorders and improve the microcirculation (Li et al., 2004).

Despite the little knowledge about the pharmacological action of QA, this plant is being frequently studied as an adjuvant or major product in the treatment of a series of diseases because of its anti-malarial (Cachet et al., 2009; Houël et al., 2009), analgesic and anti-edema (Toma et al., 2003), anti-fungal and anti-bacterial (Ajaiyeoba \& Krebs, 2003), anti-ulcerogenic (Toma et al., 2002), and male anti-fertility actions (Njar et al., 1995; Parveen et al., 2003), among others. The QA is a bush measuring 2-6 $\mathrm{m}$ high from the Simaroubaceae family. Because of its wide geographical distribution, it has many popular names, such as "Amargo", "Hombre Grande”, "Pau Quassia”, "Marubá", "Marupá", "Quina de Caiena" (Toma et al., 2003).

As QA is used in popular medicine for the treatment of diabetes, this study aimed at testing the hypoglycemic effect of the wood powder of QA in normal and alloxan-induced diabetic rats, as a possible adjuvant method in the treatment of DM.

\section{MATERIAL AND METHODS}

\section{Animals}

It was used male Wistar rats weighting between 250 and $280 \mathrm{~g}$. The animals were placed in an animal house at constant temperature of $23^{\circ} \mathrm{C}$ and automatically controlled photoperiod (12 $\mathrm{h}$ light/12 $\mathrm{h}$ dark). The animals were freely fed with standard rodent chow (Nuvilab ${ }^{\circledR}$ ) and tap water.

The experimental protocols were carried out according to the guidelines of the Brazilian College of Animal Experimentation (COBEA) with the approval of the Animal Ethics Committee of the State University of Maringá (CEAE - 061/2010).

\section{Diabetes induction}

Before diabetes induction the animals were fasted for 12 hours and then anesthetized with i.p. sodium thiopental $(40 \mathrm{mg} / \mathrm{kg}$ ) (Schanaider \& Silva, 2004). Alloxan at $2 \%$ was administered through the penile vein at the dose of $40 \mathrm{mg} / \mathrm{kg}$ and about 30 minutes later the animals were allowed to eat (Lerco et al., 2003). To confirm the diabetic state, the plasma blood glucose was checked on the sixth day after the alloxan injection and only the animals showing prandial glycemia equal to $280 \mathrm{mg} / \mathrm{dl}$ or higher were selected. The experiments were carried out on the seventh day.

\section{Preparation of QA}

The wood powder of QA (Santosflora ${ }^{\circledR}$ ) was purchased at a pharmacy of natural products. The powder was obtained from the sun-dried wood of the plant (lot QUASP01/0409). The dose used was $200 \mathrm{mg} / \mathrm{kg}$ body weight. As the sensitivity to heat of the bioactive extract is not known, the aqueous preparation was made with water at room temperature.

\section{Experimental procedure}

The anti-hyperglycemic effect of QA was investigated through the oral glucose tolerance test. Normal and diabetic rats were randomly assigned to three groups of six animals each, receiving oral administration (gavage) of $0.9 \%$ saline, metformin $(500 \mathrm{mg} / \mathrm{kg})$ or QA $(200 \mathrm{mg} / \mathrm{kg})$.

According to the experimental protocol adopted (Souza et al., 2009), blood glucose was measured after a 12-hour fast. Next the animals of each group received either saline, metformin or QA and after 30 minutes, glucose gavage at the dose of $1 \mathrm{~g} / \mathrm{kg}$. Blood glucose was measured 30,60, 90 and 120 min after the administration of glucose.

All the blood glucose values were obtained using reagent strips (MedSense - Optium) coupled to a portable digital glucose meter (Optium Xceed). The blood was sampled from the caudal vein.

\section{Statistical Analysis}

The glycemic values were expressed as $\mathrm{mg} / \mathrm{dl}$ and the data are presented as mean \pm SEM of 6-8 animals. The significance level was $5 \%$. The calculation of the area under the curve (AUC) and the statistical analysis (ANOVA followed by Bonferroni) were carried with using GraphPad Prism software (version 4.0).

\section{RESULTS}

Figure $1 \mathrm{~A}$ shows the glycemic profile of the normal rats during 120 minutes after an oral load of glucose $(1 \mathrm{~g} / \mathrm{kg})$. Thirty minutes after glucose, control 
rats (previously treated with saline) had a significant rise of blood glucose. This was not prevented by the previous treatment with QA or metformin. At 60 minutes the glycemic values of the three groups went back to the basal values and remained as such for the rest of the period.

The AUC values of figure $1 \mathrm{~B}$ show that there was no significant difference in the response of the three groups during the period of 120 minutes.

Figure $2 \mathrm{~A}$ shows the glycemic curves of alloxan-induced diabetic rats. The control animals (receiving saline) showed a significant rise of blood glucose at 30 and 60 minutes $(230,67 \pm 26,12$ and $239,17 \pm 36,52$, respectively) after the oral glucose load. The values obtained at these time intervals after the administration of QA $(126,43 \pm 8,48$ and $108,00 \pm 12,73$, respectively) and metformin $(117,00 \pm 18,84$ and $102,00 \pm 16,19$, respectively), however, showed a prevention the glycemic rise after the glucose load. The AUC values of these two groups of animals were not significantly different (figure 2B).

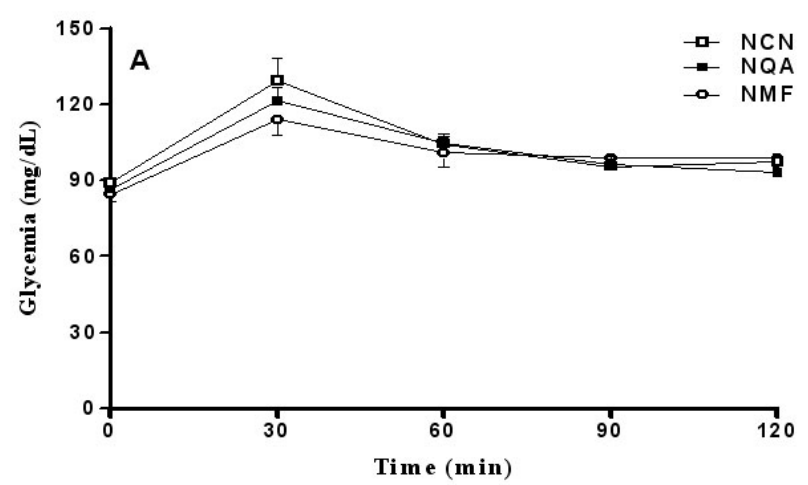

\section{DISCUSSION}

This work is the first demonstration of the anti-hyperglycemic property of the wood powder of QA using experimental animals, thus giving support to its popular use in the treatment of diabetes.

Phytochemical analyses of QA revealed the existence of numerous compounds, such as $\beta$-carbonile and indole alkaloids, steroids and the bitter quassinoids principles (Toma et al., 2003), with hypoglycemic effects described in some studies (Negri, 2005; NoorShahida et al., 2009). The quassinoids are a class of substances found almost exclusively in plants of the Simaroubaceae family and exhibiting a wide range of biological activities (Almeida et al., 2007).

In our study, QA exerted an antihyperglycemic effect in alloxan-induced diabetic rats, this model is comparable to type I diabetes, with almost complete destruction of the pancreatic $\beta$-cells (Lima et al., 2001).

The effect was similar to that observed with

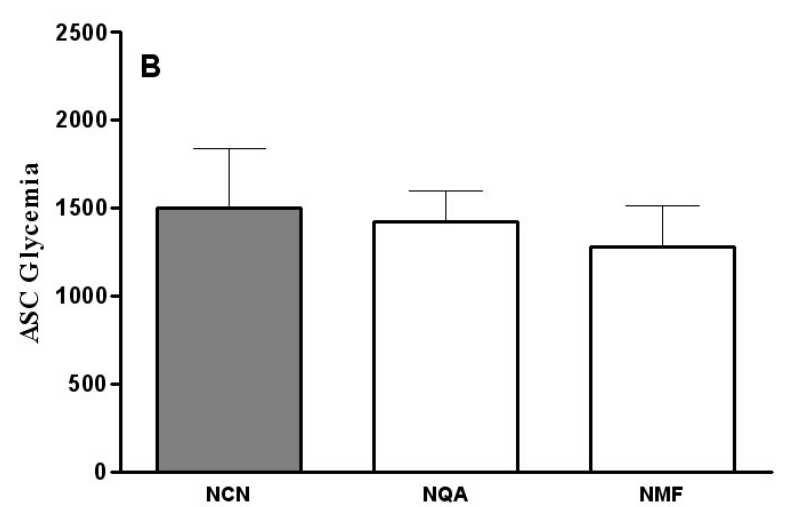

FIGURE 1. A. Blood glucose profile during 120 minutes after oral administration of $1 \mathrm{~g} / \mathrm{kg}$ of glucose, in normal rats, subjected to gavage of $0.9 \%$ saline (NCN), QA (NQA) or metformin (NMF). The glycemic values are expressed in $\mathrm{mg} / \mathrm{dl}$. B. Area under the curve (AUC). The data represent the mean \pm SEM of 6-8 animals.
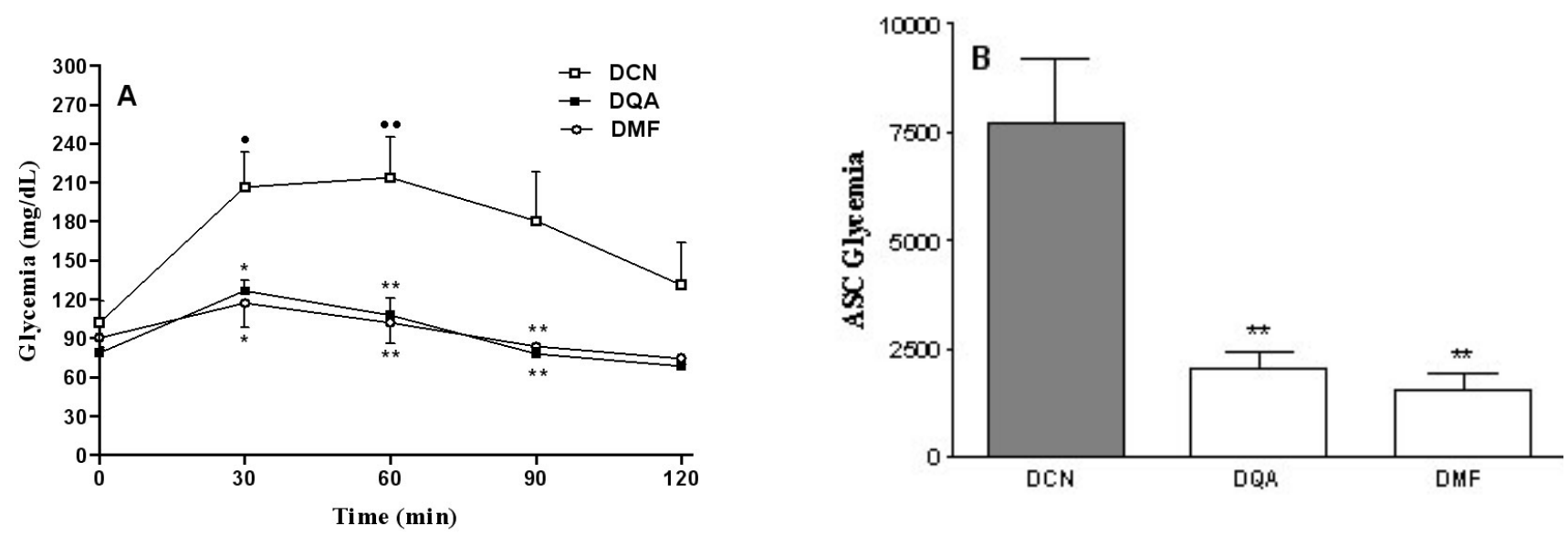

FIGURE. 2. A. Blood glucose profile during 120 minutes after oral administration of $1 \mathrm{~g} / \mathrm{kg}$ of glucose, in alloxaninduced diabetic rats, subjected to gavage of $0.9 \%$ saline (DCN), QA (DQA) or metformin (DMF). The glycemic values are expressed in $\mathrm{mg} / \mathrm{dl}$. B. Area under the curve (AUC). The data represent the mean $\pm \mathrm{SEM}$ of 6-8 animals. $" p<0.05$ and $" p<0.01$ vs 0 minutes and ${ }^{*} p<0.05$ and ${ }^{* *} p<0.01$ vs $D C N$. 
metformin, preventing glycemic changes after an oral load of glucose. The metformin is a biguanide of therapeutic use known as an oral hypoglycemic agent that acts inhibiting gluconeogenesis and, in the presence of insulin, stimulating peripheral glucose uptake, in addition to decreasing glucose absorption by the gastrointestinal tract (Fisman et al., 2004). Studies have shown that metformin does not act as insulin secretagogue and its action does not result in the an episode of hypoglycemia (Silva-Costa et al., 2008; Krents \& Bailey, 2005). It also prevents the desensitization of the pancreatic islets in the presence of glucose (Marchetti et al., 2004).

Also similar to metformin, the QA did not show hypoglycemic effect in normal rats subjected to the oral glucose load. Similar results were found in normal rats under 12-hour fast when other extracts were administered at the dose of $200 \mathrm{mg} / \mathrm{kg}$ (Souza et al., 2009), showing that plant products have only a marginal hypoglycemic effect under these circumstances (Ajikumaran et al., 2006).

The mechanism of action of QA as an antihyperglycemic agent is not yet known. However, the hypoglycemic effect of quassinoids was compared with glibenclamide in STZ-induced diabetic rats and normoglycemic mice, possibly acting as an insulin secretagogue on surviving $\beta$-cells of islets of Langerhans (NoorShahida et al., 2009).

A study showed that the anti-diabetic action of garlic can be caused by an improvement in the use of glucose by the cells of diabetic rats, showing an activity as intense as insulin or glibenclamide. This activity could be explained by a greater control over lipid peroxidation, in addition to an stimulating effect over insulin secretion (Augusti \& Sheela, 1996; Kiss et al., 2006).

The results found in this study, however, suggest that the mechanism of action of QA can be similar to that of metformin, once both elicit the same response in normal and diabetic rats. Additional investigations are necessary to test this hypothesis.

There is an ever-increasing number of scientific studies confirming the toxicity of plants until then used unrestrictedly and indiscriminately. In our study we used an oral dose of $200 \mathrm{mg} / \mathrm{kg}$ of the aqueous preparation of wood powder QA. Other investigations have shown that there is no sign of toxicity when high oral doses were tested in rats (Parveen et al., 2003; Mello et al., 2009), mice (Garcia et al., 1997; Mello et al., 2009) and rabbits (Mello et al., 2009). The QA is included in the "green list" of the Food and Drug Administration (FDA) as generally safe; its major bitter agent, quassina, is approved as food additive.

In conclusion, the oral administration of the aqueous preparation of wood powder of QA did not show significant results in normal rats, but showed anti-hyperglycemic effect in alloxaninduced diabetic rats. Although the mechanism of the anti-hyperglycemic action of QA has not been investigated, we can suggest a mechanism comparable to that of metformin, once that both presented similar results in the conditions tested. It is believed that the use of QA by diabetic individuals can help in the control of the blood glucose level as an alternative adjuvant therapy.

\section{AKNOWLEDGEMENTS}

The experimental procedures were carried out with the help of the technicians Elizete Rosa dos Santos e Valéria Romão of the Laboratory of Human Physiology.

\section{REFERENCE}

AJAIYEOBA, E.O.; Krebs, H.C. Antibacterial and antifungal activities of Quassia undulata and Quassia amara extracts in vitro. African Journal of Medicine and Medical Sciences, v.32, n.4, p.353-356, 2003.

AJIKUMARAN, N.S. et al. Anti-diabetes and hypoglycaemic properties of Hemionitis arifolia (Burm.) Moore in rats. Journal of Ethnopharmacology, v.106, p.192-197, 2006.

ALMEIDA, M.M.B. et al. Ocorrência e atividade biológica de quassinóides da última década. Química Nova, v.30, n. 4, p. 935-951, 2007.

AUGUSTI, K.T.; SHEELA, C.G. Antiperoxide effect of S-allyl cysteine sulfoxide, an insulin secretagogue, in diabetic rats. Experientia, v.52, p.115-120, 1996.

BORGES, K.B.; BAUTISTA, H.B.; GUILERA, S. Diabetes - utilização de plantas medicinais como forma de tratamento opcional. Revista Eletrônica de Farmácia, v.2, p.12-20, 2008.

CACHET, N. et al. Antimalarial activity of Simalikalactone E, a new quassinoid from Quassia amara L. (Simaroubaceae). Antimicrobial Agents and Chemotherapy, v.53, n.10, p.4393-4398, 2009.

FELIG, G.; BERGMAN, M.; FELIG, C. The Endocrine Pâncreas: Diabetes mellitus, 3 ed. New York: MacGraw-Hill, 1995, p.1107-1250.

FERREIRA, E.B. et al. Hypoglycemic effect of the hydroalcoholic extract of leaves of Averrhoa carambola L. (Oxalidaceae). Brazilian Journal of Pharmacognosy, v.18, n.3, p. 339-343, 2008.

FISMAN, E.Z. et al. Oral antidiabetic therapy in patients with heart disease. Herz, v.29, p.290-298, 2004.

GARCIA, G.M.; GONZÁLEZ, C.S.M.; PAZOS, S.L., Pharmacologic activity of the aqueous Word extract from Quassia amara (Simarubaceae) on albino rats and mice. Revista de Biología Tropical, v.44-45, p. 47-50, 1997.

GROOVER, J.K.; YADAV, S.; VATS, V. Medicinal plants of India with anti-diabetic potential. Journal of Ethnopharmacology, v.81, p.81-100, 2002.

HOUËL, E. et al. Quassinoid constituents of Quassia amara L. leaf herbal tea. Impact on its antimalarial activity and cytotoxicity. Journal of Ethnopharmacology, v.126,n.1, p.114-118, 2009.

Rev. Bras. Pl. Med., Campinas, v.15, n.2, p.230-236, 2013. 
KISS, A.C.I. et al. Efeito do extrato aquoso de Allium sativum $L$. sobre parâmetros bioquímicos em ratas com diabetes induzido por Streptozotocin. Revista Brasileira de Plantas Medicinais, v.8, p.24-30, 2006.

KRENTS, A.J.; BAILEY, C.J. Oral antidiabetic agents: current role in type 2 diabetes mellitus. Drugs, v. 65, p.385-411, 2005.

LERCO, M.M. et al. Experimental alloxan diabetesinduced: a model for clinical and laboratory studies in rats. Acta Cirurgica Brasileira, v.18, n.2, p.132-142, 2003.

Li, W.L. et al. Natural medicines used in the traditional Chinese medical system for therapy of diabetes mellitus. Journal of Ethnopharmacology, v.92, n.1, p.1-21, 2004.

LIMA, M.A. et al. Análise quantitativa das células das ilhotas pancreáticas em ratos sob efeito de aloxana. Medicina, v. 34, p.308-314, 2001.

MARCHETTI, P. et al. Pancreatic islets from type 2 diabetic patients have functional defects and increased apoptosis that are ameliorated by metformin. The Journal of Clinical Endocrinology and Metabolism, v.89, n.11, p. 5535-5541, 2004.

MEDEIROS, J.S. et al. Ensaios toxicológicos clínicos da casca do maracujá-amarelo (Passiflora edulis, f. flavicarpa), como alimento com propriedade de saúde. Revista Brasileira de Farmacognosia, v.19, n.2, p.394-399, 2009.

MELLO, J.R.B.; MELLO, F.B.; LANGELOH, A. Toxicidade pré-clínica de fitoterápico contendo Aloe ferox, Quassia amara, Cynara scolymus, Gentiana lutea, Peumus boldus, Rhamnus purshiana, Solanum paniculatum e Valeriana officinalis. Latin American Journal of Pharmacy, v.28, n.1, p.183-191, 2009.

NEGRI, G. Diabetes melito: plantas e princípios ativos naturais hipoglicemiantes. Revista Brasileira de Ciências Farmacêuticas, v.41, n.2, p. 121-142, 2005. NJAR, V.C. et al. Antifertility activity of Quassia amara: quassin inhibits the steroidogenesis in rat Leydig cells in vitro. Planta Medica, v.61, n.2, p.180-182, 1995.

NOORSHAHIDA, A.; WONG, T.W.; CHOO, C.Y. Hypoglycemic effect of quassinoids from Brucea javanica (L.) Merr (Simaroubaceae) seeds. Journal of
Ethnopharmacology, v.124, p. 586-591, 2009.

PARVEEN, S. et al. A comprehensive evaluation of the reproductive toxicity of Quassia amara in male rats. Reproductive Toxicology, v.17, n.1, p.45-50, 2003.

PROVASI, M. et al. Efeito do extrato bruto hidroalcoólico e de frações de folhas da Averrhoa carambola L. (Oxalidaceae) no metabolismo glicêmico de ratos Wistar. Acta Scientiarum Health Science, v.27, n.1, p. 45-48, 2005.

RAHEJA, B.S. Oral hypoglycemic agent in the management of Maturity-Onset Diabetes-A: Reprint". Reassessment. Journal J. J. Group Hospitals Grant Medical College, v.22, p.1-9, 1977.

ROSAC, C. The pathophysiological basis of efficacy and clinical experience with the new oral antidiabetic agents. Journal of Diabetes and its Complications, v.16, p.123-132, 2002.

SCHANAIDER, A.; SILVA, P.C. Uso de animais em cirurgia experimental. Acta Cirurgica Brasileira, v.19, n.4, p.441-447, 2004.

SEBBAG, L. et al. Effect of experimental non-insulin requiring diabetes on myocardial microcirculation during ischaemia in dogs. European Journal of Clinical Investigation, v.24, n.10, p.686-690, 1994.

SILVA-COSTA, E. et al. Metformin interacts with physical training decreasing glycemia and increasing glycogen supply in diabetic rats. Revista Brasileira de Medicina do Esporte, v.14, n.4, p.337-340, 2008.

SOUZA, V.H. et al. Avaliação do potencial antidiabético de cinco plantas medicinais em ratos. Latin American Journal of Pharmacy, v.28, n.4, p.609-612, 2009.

TOMA, W. et al. Antiulcerogenic activity of four extracts obtained from the bark wood of Quassia amara L. (Simaroubaceae). Biological \& Pharmaceutical Bulletin, v.25, n.9, p.1151-1155, 2002.

TOMA, W. et al. Evaluation of the analgesic and antiedematogenic activities of Quassia amara bark extract. Journal of Ethnopharmacology, v.85, n.1, p.19-23, 2003.

TOSCANO, C.M. As campanhas nacionais para detecção das doenças crônicas não-transmissíveis: diabetes e hipertensão arterial. Ciência da Saúde Coletiva, v.9, n.4, p.885-895, 2004. 